\title{
A NEW REVOLUTIONARY PRACTICE: OPERAISTI AND THE 'REFUSAL OF WORK' IN 1970'S ITALY
}

Uma nova prática revolucionária: obreiristas e a "recusa do trabalho" na Itália da década de 1970

Una nueva práctica revolucionaria: obreristas y el “rechazo al trabajo" en Italia en la década de 1970

NiCOLA PIZZOLATO

http://dx.doi.org/10.1590/S2178-14942017000200008

Nicola Pizzolato is a Senior Lecturer at the Institute for Work Based Learning, Middlesex University London.

Article received on 1 February and approved for publication on 4 May 2017. 


\begin{abstract}
The social protest that engulfed Italy in the 1970s found a theoretical analysis in the work of the operaisti. Through a series of concepts, they outlined a new revolutionary practice that aimed to return to a more authentic reading of Marxism. This article focuses on the notion of 'refusal of work' and the ancillary concept of 'appropriation' and examines how these theoretical tools emerged out of radical protest in factories and were put forward by the operaisti as a central plank of a revolutionary strategy for the working class.
\end{abstract}

KeYwords: radical politics; marxist theory; Operaismo; social protest; Italy.

\title{
RESUMO
}

Os protestos sociais que tomaram conta da Itália na década de 1970 ganharam fundamentação teórica no trabalho dos obreiristas. Estes, com base numa série de noções, delinearam uma prática revolucionária nova, encarada como retorno a uma interpretação mais autêntica do marxismo. 0 presente artigo trata da noção de "recusa do trabalho" e do conceito associado de "apropriação", examinando de que modo estas ferramentas teóricas se modelaram nos protestos radicais nas fábricas e foram apresentadas pelos obreiristas como plataforma central de uma estratégia revolucionária para a classe trabalhadora.

PalaVRas-ChaVE: política radical; teoria marxista; obreirismo; protesto social; Itália.

\section{RESUMEN}

Las protestas sociales que dominaron Italia en la década de 1970 obtuvieron fundamentación teórica en el trabajo de los obreristas. Con base en una serie de nociones, delinearon una práctica revolucionaria nueva, considerada como el regreso a una interpretación más auténtica del marxismo. El presente artículo trata de la noción de "rechazo al trabajo" y del concepto asociado de "apropiación", examinando de qué modo estas herramientas teóricas se moldaron en las protestas radicales en las fábricas y fueron presentadas por obreristas como plataforma central de una estrategia revolucionaria para la clase obrera.

Palabras ClaVE: política radical; teoría marxista; movimiento operario; protesta social; Italia 
n Italy at the onset of the 1970s a diverse group of workers, intellectuals, and political activists on the left of the Italian Communist Party (PCI) developed a critical standpoint towards the 'orthodox' Marxism of the old Left. Notwithstanding internal differences, these political protagonists of the social and workers' protests that engulfed Italy in the 1960s and the 1970s were loosely labelled as operaisti (usually translated into in English as 'workerists', a word which, confusingly, has different meanings in different contexts, such as in the case of Brazil's trabalhismo). With a theoretical reflection that evolved hand in hand with the advances and retreats of workers' struggles, the operaisti sketched the contours of a new revolutionary practice that aimed, or claimed, to return to a more authentic reading of Marxism, in opposition to the 'reformist' stance of the PCI (Italian Communist Party) and the totalitarian regime of the Soviet Union. This article examines the link between key ideas that emerged from operaisti thought, in dialogue and in juxtaposition with the variegated social protest of 1970s Italy, focusing in particular on the idea of the 'refusal of work' as a central plank of a revolutionary strategy in times of the restructuring of capital.

The 1969-1973 period involved a remarkable level of industrial conflict, often in a self-organised form, by workers with the assistance of students. Conflict spread from the core of Italian industrial capitalism - FIAT in Turin, Pirelli in Milan, the Petrochemical plants of Porto Marghera - to the majority of industrial workplaces and the public sector. This period started with the explosive mobilization of the 1969 autunno caldo, the 'hot autumn', in Turin, but the insurgency did not stop even after the passing in 1971 of the Statuto dei lavoratori (the Workers' Charter) - a major labour reform which brought Italian industrial relations into line with those of other major capitalist nations and actually with terms comparatively more favourable to workers (Regalia and Regini, 1998). In some respects, it could be said that the effect of the Statuto dei lavoratori was comparable to the Wagner Act (1935) in the US, in that it represented a major victory for the labour movement but it was eventually instrumental in stifling strident militancy on the shop floor. Ironically, in the US that model of industrial relations would enter a period of crisis precisely in the 1970s, undermined by an economic recession, industrial restructuring, and relocation, as well as dwindling support from the rank and file (Lichtenstein, 2002).

In 1971 and 1972, radical groups such as Lotta Continua and Potere Operaio, which had facilitated the alliance between the student movement of 1968 and the autonomous 
workers' movement of 1969, still had many followers in the factories, in particular the large ones, but they were no longer able to command the bargaining agenda. Trade unions, now protected under the terms of the Statuto, had a structure that enabled workers to voice their claims through an institutional channel (which had not been readily available in most of the 1950s and 1960s). In the process of reaching out to radicalised workers, unions had themselves become more democratic. Shop floor bargaining became the norm in the automobile factories of Turin to such an extent that foremen even micro-bargained the speed of the line with the shop delegate at the start of every shift. This amounted to management negotiating production targets with unions, an astounding accomplishment (Contini, 1986).

In 1973, after a two-year period in which radicals had been very vocal but enjoyed diminishing support, workers were again on the barricades at Mirafiori, FIAT's flagship plant in Turin, where they had achieved their greatest success. From November 1972 to March 1973, FIAT autoworkers fought for the most progressive contract up to that point, the last significant gain before an era of company restructuring and relocations outside Turin and Italy, which would permanently alter the balance of power. The occupation of Mirafiori, which was orchestrated autonomously by radical workers, was an event of national importance due to its political and symbolic consequences, and it was also the peak of the radical movement of the non-instutionalised (extra-parliamentary) Left; from that point on, it would begin to slip into oblivion. The economic recession triggered by the oil crisis bolstered the firm's policy of relocation and state-assisted redundancies (cassa integrazione), which appeared to be the best solution to respond to the shop floor upheaval of the previous years. In the early 1970s, cassa integrazione became a tool that large manufacturers such as Indesit (Turin and Caserta), Lanerossi (Schio and Foggia), Philco (Bergamo), Borletti and Pirelli (Milan), and many other large employers used to eradicate industrial conflict in factories, while at the same time indirectly funding company restructuring (Longo, 1975). At FIAT, which led the way in terms of the strategy of capital against workers' empowerment, managers used an array of tools to diffuse conflict. They leveraged plant-level mobility, between shops and departments, and company-wide mobility, between different plants, to break up the most militant teams. Cassa integrazione was used to make the most combative departments redundant and relocate their production to other plants or automate it. Other manufacturers followed suit on a smaller scale (Linea di Condotta, 1975; Longo, 1975).

The decline of radical struggle allowed trade unions and, at the electoral level, the $\mathrm{PCl}$ (the Italian Communist Party), both of which were seen by radicals as reformist forces instrumental to capitalism, to regain consensus and control in the large factories of the northwest of the country, further undermining groups such as Potere Operaio and Lotta Continua. The PCI 
would go on to receive over one third of the votes in the 1976 general elections. In the same year, Lotta Continua dissolved, as Potere Operaio had done previously in 1973. Radical politics continued to survive within smaller groups, but none were able to command the influence of those more popular organisations. In the second half of the 1970s, the phrase 'autonomia operaia' was used to describe the constellation of students, intellectuals, and workers who built on the legacy of operaismo and engaged in forms of social protest antagonistic to the state as well as to left-wing institutions such as the trade unions or the $\mathrm{PCl}$. In Milan and Porto Marghera autonomisti formed factory committees (for instance at Alfa Romeo and Sit Siemens). As an arena of dissent critical of the Communist party, autonomia established a visible presence in Rome, Padua, and Bologna, which were not core industrial cities. Bologna became the centre of the movement after the police murdered Francesco Lorusso, a former Lotta Continua militant, in 1977. The spread of the proletarian struggle beyond the industrial working class was a novelty of the 1973-1979 period.

Although often differing in their tactical analyses, many of the radicals who drove the protests still subscribed to the (evolving) ideas developed in the 1960s by operaisti such as Raniero Panzieri, Mario Tronti, Romano Alquati, and Toni Negri, amongst others. The genesis of operaismo lay in the post-1956 disenchantment of leftist intellectuals with the Soviet Union after the repression of the Hungarian uprising and Krushev's 'Secret speech'. In opposition to what they saw as the endless political manoeuvring of the Italian Communist and Socialist parties, supported by the leftist trade unionists, operaisti advocated focusing on the factory and its workers, as the key to the revolutionary project of the Left - one that the Italian Left had seemingly abandoned, at least de facto. However, operaismo had always multiple voices, and its theory evolved in parallel with the political landscape, drifting, as we shall see, towards a conceptualisation of the working class much beyond the factory walls.

\section{THE PERSPECTIVE OF OPERAISMO}

$\mathbf{C}$ he idea at the base of workerism", wrote Sergio Bologna retrospectively, "was that the large factory with its thousands of workers could become a large fertile terrain for a revolutionary project, and shift from the site of mass production to a space liberated from capitalist oppression" (Bologna, 2014). Operaisti emphasized: the autonomous agency of the working class, outside unions and political parties, in the form of grassroots activity and self-organisation on the shop floor and, later, beyond the factory; the idea that capitalism was reactive to the workers' struggle (rather than its opposite) and workers' struggles as a political variable uncontrollable by capitalism; a service role of intellectuals in relation to the working 
class, but not one of direction, in a Leninist sense; the recognition that technology was not a neutral tool, but one used to undermine workers' control; the belief in the existence of a capitalist 'plan' to neutralise class conflict, in synergy with the economic policy of the state; the idea of 'class composition', in other words, the diverse composition of technical skills and the cultural and political identity of the working class; and the endorsement of sabotage and the refusal of work as legitimate forms of political action (Tronti, 1966; Panzieri, 1994; Wright, 2002; Trotta and Milana, 2008).

Many of these ideas had blossomed in the 1950s and early 1960s in a transnational dialogue with American and French dissident Marxists, most prominently C.L.R James, Raya Dunayvskaya, Grace Lee Boggs and Martin Glaberman from the Trotskyist splinter group originally called the Johnson-Forest Tendency, as well as the French writers Cornelius Castoriadis, Claude Lefort and Daniel Mothè from Socialisme ou Barbarie (Pizzolato, 2011; Cleaver, 1979: 59-76). More specifically, the Johnson-Forest Tendency had drawn on the history and contemporary observations of the American working class, both white and black, to argue that workers displayed a capacity for self-organization, self-management, and instinctive adversity to the workings of capitalism even outside and beyond the labour movement, and, indeed, outside and beyond knowledge of Marxism as it had been propagated by the Communist party (Glaberman, 1999).

In turn, the workerist analysis of the 1960s had focused on the emergence of what they called the 'mass worker' as the central subject of Italian capitalism, who, in terms of 'class composition', was young, unskilled, often an immigrant southerner, and working on the assembly line. This was a political subject who had emerged in the US during the time of the New Deal (Negri, 1972). In Italy, the 'mass worker', typically a male, worked in a Fordist factory and was paid a family wage which guaranteed his reproduction. He occupied a strategic position in the Fordist production process, which meant that, at least in the 1960s, he (rarely a she) was made the linchpin of the whole revolutionary strategy of the operaisti, who summed it up in the idea of 'worker centrality'. In fact, the operaisti sought to wrest the mass worker from a capitalist 'plan' that presented itself in the benign manifestation of 1) national unions engaged in bargaining for incremental benefits at the expense of worker control at the point of production, and 2) reformist left parties, including the $\mathrm{PCl}$, which emphasised electoral participation and parliamentary action instead of grassroots activity (Negri, 2005: xxxii-xxxiv).

The 'plan' of modern capitalism encompassed the whole society and shaped it according to the will of the class of capital a capitalist collective that forced the single capitalist to align themselves with the general needs of the system. According to operaismo, the plan of capital aimed to neutralise class conflict through the manipulation of the buffer activity of 
trade union and reformist politics, embodied, ironically, by the staid PCI. Intuitively antagonist to this project, workers undermined the plan with their 'strategy of refusal' (a phrase coined by Mario Tronti) - the refusal to work more, faster or better. Anathema to the $\mathrm{PCl}$, whose political culture was rooted in the, now obsolete, productive ethos of the craft worker; the 'strategy of refusal' well described the gut reaction of the young, unskilled workers, many of whom were southern migrants, to the unhealthy and alienating environment of the factory.

Against the position that workers developed their class identity only within the Party a view congruous with the fact that those who advocated it were Communist Party members - the operaisti embraced Workers Inquiry (a return to Marx's unfulfilled project) as a means of understanding their actual political subjectivity as it emerged within the factory. As Italian industries caught up with Fordism in the 1950s, the task of understanding the working class was all the more urgent because of the radical transformation of the production process as well as the recruitment of southern immigrants, generally regarded as eschewing class conflict. Workers inquiries were first published in the cradle of Italian operaismo, Quaderni Rossi, edited by Raniero Panzieri, and were regarded as a controversial tool of political intervention. Orthodox Marxism regarded sociology and its methods as an intellectual tool of capitalism, aimed to further its interests. This prompted Panzieri to write a seminal article in its defence, 'The Socialist Uses of Workers Inquiry', in which he defined the importance of this tool as an integral part of political intervention and revolutionary change (Fasulo, 2014). Later 'co-research', an offspring of workers' inquiry developed by Romano Alquati, was a methodology based on dialogue between workers and intellectuals that would result in a political analysis of the situation which in turn often informed action through flyers, pamphlets, and the political statements of the radical groups. Thus, operaismo was composed of several interlocking layers, intermixing, in its best moments, theory, methodology and political activism.

These practices responded to the interconnected needs to educate workers and to educate political activists about the nature of the antagonistic subjectivity of workers. They would be the foundation of the key theoretical insight of operaismo, that workers are not only an element of the production of capital, but autonomous agents, to which capital is often reactive, and therefore worth studying in their own right. In the 1960s - starting with the Piazza Statuto riot in Turin in 1962, and until the 1969 wave of strikes - Italian workers had shown considerable willingness to oppose capital not only on economic terrain (i.e., contractual benefits, within the framework of the trade unions), but on a political ground, undermining the whole system. Or at least this was the reading of the operaisti; in reality the weakness of the unions in relation to employers was an important element in understanding the absence of a framework to channel protest in a reformist direction, at least until the Statuto dei Lavoratori 
(1971). The strength of the unions within the factory during the 1970s would prompt the operaisti to analyse how autonomous social conflict, diminishing in the industrial plants, could shift to the whole society.

\section{'APPROPRIATION' IN THE TIMES OF THE 'SOCIAL FACTORY'}

s outlined above, the approach of the operaisti focused on the factory and on industrial
workers - perhaps too much so, betraying their strong bias towards the heavy industry factories of the Northwest. But during the 1960s workerism also developed the idea of the 'social factory', which would evolve in a way that would be applicable outside of Italy's northern industrial heartland and would be the key to understanding the widespread social struggles of the 1970s, as well as the predicament of the working class during that decade of industrial restructuring and relocation. According to Mario Tronti, capitalist development was growing to encompass society "to the point where the entire society existed as means for the ends of capitalist production" (Palazzi, 2014). In Tronti, the suggestion of the 'social factory' did not imply that the factory was losing its centrality - this was not the case in the 1960s - but that the society as a whole was subjugated to the aim of capitalist production, so that the workings of the factory ramified far beyond its physical perimeter. This was a notion of a society and, therefore, of a political strategy, that still had the factory as its fulcrum, whose presence cast a shadow upon the rest of social interaction, shaping it in function of the ultimate goal, namely production, distribution, and the realization of profit for the capitalist class. Following Tronti, the 'social factory' became a more expanded way of thinking about social relations between classes, which implied a proletarization that went beyond the industrial sector into the tertiary sector (Tronti, 1962).

This conceptualization of the 'centrality' of the factory worker in revolutionary practice entered a crisis in Italy after 1973 and the 'climax' of the occupation of the FIAT Mirafiori plant. Between 1973-1979, the intellectual tradition that originated with the operaisti (and then transmuted into 'autonomia) had to confront the transformation of the political economy, through restructuring, relocation, steep inflation, austerity, and the rise of political 'subjectivities' which did not inhabit the industrial workplace. In response, Antonio Negri developed an influential and controversial analysis that expanded the notion of 'social factory' beyond the realm of production into the realms of reproduction and consumption introducing the idea of 'socialised worker'. In his reading, the subjectivities of the social factory were proletarian, but not necessarily factory workers. They included women, students, the unemployed, and homosexuals. Operaisti had traditionally deployed the analytical tool of 'working class composition' 
to dissect the varieties of political positionalities of workers in relation to the production process. In the 1970s, to understand the composition of the working class one had to look also beyond the factory insofar as anti-capitalist identities were also built in the 'territory'. The locations of the working class attack on capital could also include the community, the household, the school (Negri, 1976).

The theoretical shift necessary to embrace the multifaceted social conflict of 1970s Italy involved sharpening some of the notions developed by operaismo in the late 1960s and redeploying them in the changed political context. During the 'Hot Autumn', insurgent workers had turned the tables on trade unions' bargaining strategy, which traded higher wages for higher productivity, and unified under the slogan più soldi e meno lavoro, 'more money and less work'. The 1973 occupation had been driven not by a demand for worker control but by a desire to end waged and alienated labour. Strikers on that occasion had occupied the factory not to run it, but to stay idle (Rosso, 1973). The tradition of the PCl, going back to Antonio Gramsci and the experience of the Factory Councils in 1919-20, revolved around the aspiration of 'worker control', which to some operaisti appeared increasingly delusional in the era of the 'mass worker' and, even more, in times of restructuring and rising unemployment. (Operaisti were critical of Gramsci in other respects too, pointing out the failure of the idea of the 'organic intellectual' as a Communist party organiser) (Tronti, 1966). In contrast, they endorsed the twinned concepts of 'refusal of work' and 'appropriation'. These originated in the ideas that Tronti had outlined when claiming the significance of the 'strategy of refusal' for Marxist theory. In his view, productive labour constituted the basis of capitalist political power. Any struggle to change the conditions of labour would end up playing into capitalists' hands as it only led to a change in the way their power was articulated politically, resulting, simply put, in an 'improvement of exploitation'. The only act that would challenge the political power of the capital at its core, was to organise the withdrawal of labour altogether. This would open a systemic crisis that would lead to the 'destruction of the present society' (Tronti, 1966). In the 1970s, refusal of work encompassed more than just strikes and production stoppages, the hallmarks of the 'Hot Autumn', including also practices that were being 'autonomously' deployed by the working class, such as absenteeism and withdrawing from the labour market, or shunning industrial employment altogether to live in the counterculture. "The working class", commented the autonomists of Rosso, "does not want to take power in the factory to work more and better, but to change altogether a way of working that nobody likes" (Rosso, 1973). "We need to leave the factory and dissolve the bond of the productive relationship", added Senza Tregua, another militant paper (Senza Tregua, 1975).

In the mid-1970s, the radical left had taken notice of the exponential increase in absences in factories and correctly recast what was usually considered as an individual choice 
into a collective political action. In 1974, 16 per cent of the workforce of the Alfa Romeo plant Portello was, on average, absent. The rate was 13.62 per cent for the Innocenti factory in Milan. But the yearly average masked wide fluctuations. In June 1974, the latter plant had registered an astonishing 31 percent of workers missing from the workplace (Centro Ricerche Sull'Autonomia Proletaria, 1976: 80). In this regard, historian Marcello Tarì has commented that, "this practice of self-defence, which had always been used by workers, became so widespread and significant that it came to be acknowledged as a form of struggle as well as a form of life, using a new language, which pointed to the withdrawal of productive time as well as to the rejection of working-class identity itself" (Tarì, 2012: 84).

The other addition to the vocabulary of protest, 'appropriation', meant both reclaiming labour time as free time and recouping, through self-reduction of bills and fees or capped prices on supermarket shopping, some of the wage loss engineered by the capitalist state through galloping inflation. According to Negri, both practices - claiming liberation from work and waged labour as well as the re-appropriation of 'social wealth' - were at the core of what could constitute revolutionary strategy in times of capitalist crisis and of the 'social factory'. While the industrial shop floor remained a privileged site for such practices, it was no longer the only one. As a result, appropriation, in its several aspects, would constitute the central plank of a truly communist attack against the state and capital (Negri, 1976).

Following the onset of the oil crisis and the related policy of austerity, Italy became home to an extensive movement of 'self-reduction', a form of appropriation of social housing rents, utility bills, and transport fares, which had spiralled upwards following inflation - a struggle initiated by the radicals in the late 1960s but which escalated in those years and in some cases was also supported by the unions (Alemanni et al, 1974). Operaisti argued that inflation was capital's plan to roll back the wage gains that workers had achieved during the previous years. It also emasculated the subversive meaning of the struggle over wages, into a simple defence of income (Marazzi, 2013: 72). Self-reduction was organised so that a reduced amount would be paid to bus companies and energy providers. At the time, these were state-owned companies. After fighting the practice with legal action the latter accepted it once the protest built momentum. Significantly, the protest started in Pinerolo, an immigrant working-class area on the outskirts of Turin, not far from FIAT Rivalta, a more recent plant constructed in 1967 to assist the production at Mirafiori, and it spread to other working class neighbourhoods and eventually to other parts of the industrial north as well as Rome, where working class families occupied social housing units (Ramirez, 1975; Villani, 2013; Cherki, Viviorka, 1980). It is, however, in the industrial area most affected by the struggle of the previous years that self-reduction become a widespread phenomenon. In the working-class suburban ring of Turin, 
the number of self-reduced utility bills reached 130,000 in 1974. In many towns, committees of self-reduction were established, sometimes supported by the communist union branches or the local PCI branch, depending on local political conditions (Linea di Condotta, 1975). In Turin, in the working-class enclave of Le Vallette, a committee decreed the reduction of heating bills across the social housing. This was a newly built neighbourhood entirely populated by factory workers and their families, which had seen a long string of episodes of occupations of homes and clashes with the police (Rosso, 1973: 6). These practices went hand in hand with a restructuring process inside factories that saw thousands of workers facing state-assisted redundancies at a moment in which their purchasing power shrank.

The group of political militants that followed these developments most closely and elevated them to a political strategy for revolution coalesced around the little-known, but influential, publication: Rosso, which ran from 1973 to 1979, a period of deep transformation of the Italian working class. Rosso combined and disseminated the diverse voices of autonomia operaia; it gave equal attention to self-activity within the factory and the rise of rebellious subjectivities outside of it. In 1975 Rosso conceptualised appropriation as the legitimate response against "the social devastation caused by the inflation" (Rosso, 1975). The spectre of legality - continued the article - had been agitated by the bourgeois, including reformist parties and unions, to hide the fact that the real theft was the one at the expense of the workers, who saw an increasing part of their salary spent on utility bill rate hikes that the capitalists had concocted. The practice of appropriation was already widespread, but Rosso campaigned to expand it further. When applied to the industrial workplace, appropriation could be moulded into a multi-prong revolutionary strategy. For instance, by aiming to work 35 hours and be paid for 40, workers would appropriate labour-time. (This demand was put forward in those years by radical groups such as Lotta Continua). Or rather re-appropriate it, as workers' labour time was exactly what capitalists aimed to capitalise on. Through examples such as this, the autonomists could connect back to the classic historical struggles for the reduction of the working day, as well as to the more recent Italian protests inspired by the slogan più soldi, meno lavoro. For instance, in 1972 at Porto Marghera workers had defied the trade unions bargaining platform to demand a 36-hours working week.

Another interlinked demand was the one of salario garantito, 'guaranteed wages', a secure salary for workers which would be immune to the restructuring of operations within the factory (such as cassa integrazione or relocation of departments), but more broadly a secure social wage for all adults, whether workers or not. The demands for salario garantito were more pressing where workers had developed representative bodies quite independent from trade union influence, such as at Alfa Romeo, where during 1974 most workers subscribed to 
a bargaining platform strongly influenced by autonomists (Rosso, 1974: 2). In the mid-1970s, though in a changed political climate, there still remained a strong legacy of the egalitarian agenda that had been put forward during the 'Hot Autumn', with its emphasis on equal wage increases and benefits across the board, irrespective of workers' roles, qualifications, or seniority.

Finally, radicals also interpreted appropriation in a sense more compatible with the Communist tradition, controlling the production process to undermine capital's productivity, but with an autonomist twist. Or, as Rosso put it, it would mean "workers' re-appropriation of the productive process as a manifestation of power, as practical ability and knowledge, in order to destroy the capitalist logic of productivity". In this case, workers would leverage the knowledge of the production process to 'block, subtract and sabotage' and to exercise power over production (Castellano, 1980; Cunnighame, 2002: 63).

Appropriation, and the connected tactics of 'refusal of work' and 'guaranteed salary', was a malleable concept, which could be deployed in different contexts - from transport fares to the assembly line - linking them together in a coherent, if simplistic, organizational method to bring down capitalism. Appropriation was an instrument, but not the final goal, i.e., the destruction of the capitalist process itself by erasing the category of work as it was conceptualised in that system. According to Palazzi, "part of the social factory", as capitalist command outside the factory entailed moving beyond labour and production as central elements of working class theory to a focus on the consumptive enjoyment of the material needs of the working class. Appropriation, as direct action, was the expression of this theoretical turn. (Palazzi, 2014: 345).

'Refusal of work' linked the factory to the community. It also linked factory workers with other subjectivities, often from lower middle class backgrounds, who shunned work altogether to live in the counterculture. These two categories had never seemed to have anything in common. During the 1960s, 'beatniks' and 'hippies' seemed to care about individual emancipation, not about changing the system collectively. By the mid-1970s, in the light of the above categories of political organisation, autonomisti reconsidered these behaviours as more quintessentially political. They also implied a refusal of the capitalist organisation of labour and its associated work ethic. There was also now a recognition that in order to achieve political change, through the rejection of capitalist institutions such as the factory and the school, a change in culture was also necessary. According to Rosso, hippies' experiments with new lifestyles went in these directions (Rosso, 1973). However, 'appropriation' could also be trivialized and used to lend a political veneer to outright individual illegal actions, such as the esproprio proletario or 'proletarian confiscation', an ironic way to describe the robbery of 
provisions, with one of the most famous instances occurred during the counterculture festival at Parco Lambro, in Milan, in 1976 (II Manifesto, 2016). Eventually, it can be argued that the theoretical turn towards appropriation, with its praise of mass illegality, also suggested a turn towards insurrection as a central plank of the revolutionary strategy. As Potere Operaio stated, "the problem is to force the incipient movement from the terrain of appropriation towards an insurrectional path" (Palazzi, 2014: 345). Eventually left wing terrorist groups such as the Brigate Rosse misappropriated this rationale and its rhetoric to employ it on the level of vanguard insurrection, rather mass insurrection.

Could any revolutionary strategy be coherent and effective by drifting away from the sphere of direct production into social reproduction? This is where the ambivalent legacy of the practice conceptualised around the notions of 'refusal of work', 'appropriation' and 'socialised worker' lies. Negri's analysis, much criticised within the revolutionary left for casting a shadow upon the centrality of the 'mass worker' and diluting it in the vaguer 'socialised worker', attempted to mould theory into the political practices emerging after the 1973 Mirafiori occupation and find a unified explanation to what looked like a very diverse kind of political antagonism (Wright, 1996; Negri, 2005). Contrary to Negri's wishful thinking, the heterogenous moments of proletarian struggle, diffused across society, had never concretely coalesced in the political unified figure of the 'socialised worker'; it was a figure that could hardly express a unified political intent in the same way as the mass worker (Wright, 1996). There was never a common front against capital or the state during the 1970s (Battaggia, 1980: 74). Rebuking Negri, Sergio Bologna argued that the idea of drawing upon a new social subject masked the frustration for the fact that most factory workers had opted to support the unions and the communist party; it was a theoretical 'trick' that avoided confronting a main problem of the radical left, not an analysis that could spur revolutionary action (Bologna, 1976). At the same time, the 'socialised worker' described the political relevance of exploited layers of the working class that had never entered a factory and that had not found a place in Marxist theory and prefigured, though in a rather conceptual way, a post-Fordist situation in which the proletariat was not necessarily an industrial one.

\section{CONCLUSION}

he emboldened demands of the autonomists neglected to confront the reality that a
majority of workers now had found suitable redress to their grievances through mass entrance into the trade unions. Just a year after the 1973 occupation, most FIAT workers were actually eschewing radical politics by not supporting the bargaining agenda put forward by 
the autonomists. "The platform", reported Rosso, "was not understood by [FIAT] workers. And those who understood it did not believe in it" (Rosso, 1974: 2). In 1975, the autonomist campaign for a 35 hour week, much supported by Rosso, did not win the consent of the majority of metalworkers. It was a defeat that prompted self-criticism within the radical left, accused of practicing Leninist types of political organisation, centred on a novel need for a vanguard party, which did not fit entirely with the tradition of spontaneity and self-activity of operaismo and autonomia. This was exemplified by the comment of one worker who stated, "our organisation emerged from workers' autonomy, but we the workers have now lost importance in its decisions. [...] We need to claim back our role without our positions being determined from above, as in the case of the 35 hour [working week]" (Bobbio, 1979, pp. 156-8; Lotta Continua, 1976). ${ }^{1}$ As noble as it was, it seemed to be an idea parachuted onto ordinary workers, not arising from them.

The autonomists, drawing on some elements of the tradition of operaismo, developed 'the strategy of refusal', which included refusal to work and appropriation, as central to a revolutionary strategy. This political stance failed however to attract the majority of workers in the 1970s and, eventually, to spark a revolution. Given the restructuring of Italian industrial geography and the dilemmas it posed (for instance, should workers accept a factory closing or the terms of its restructuring?), the autonomist programme did not respond with a pragmatic solution, opting instead for a strategy that enjoyed little support and that consigned most workers who did not engage with it into a 'reformist' camp. On the other hand, as Patrick Cunnighame has arguably stated, it was the organizational and cultural vitality and theoretical sharpness of the autonomists, in the shadow of the operaisti, which might help to explain the slowness of the introduction of neoliberal reforms of the Italian labour market (Cunnighame, 2002: 94). Flanked by radicals on their left, trade unions kept a combative stance throughout the 1970s and beyond, even in face of the reconfiguration of the political system during the 1980s. In an environment transformed by the restructuring of the Fordist factory and the financialization of capital that we now know well, the autonomists of the 1970s brought forward a new set of theoretical possibilities for revolution and, through the concepts of appropriation and refusal of work, new practices and tools that are now material for reflection for political activists anywhere.

\section{Notes}

1 For a long time, the internal division of the LC caused by the ' 35 hours' issue continued to be debated. See 'Intervento del compagno Mario di Novara,' Lotta Continua, 28 August 1976, p. 2. 


\section{BIBLIOGRAPHY}

ALEMANNI, Ferigo, et al. Autoriduzione: cronache e riflessioni di una lotta operaia e popolare: settembre-dicembre 1974. Serafino: Sapere, 1974.

Autoriduzione alla FIAT - la prova generale. Linea di Condotta. luglio-ottobre 1975. Available at: <http:/l www.chicago86.org/archivio-storico/lotte-operaie-anni-60-70/miscellanea-lotte-operaie/96-autoriduzione-alla-fiat-la-prova-generale.html> Accessed on: 30 April 2017.

BATTAGGIA, Roberto. Operaio massa e operaio sociale: alcune considerazioni sulla 'nuova composizione di classe'. Primo Maggio, n. 14, Winter 1980-81.

Beat, Pop, Hippy. Li lasciamo alla borghesia? Rosso, anno 1, n. 3, 16 April 1973.

BOBBIO, Luigi. Lotta Continua, storia di un'organizzazione rivoluzionaria. Roma: Savelli, 1979.

BOLOGNA, Sergio. "Proletari e Stato" di Antonio Negri: una recensione. Primo Maggio, n. 7, 1976.

Workerism beyond Fordism: on the lineage of Italian workerism. Viewpoint Magazine, 15 December 2014. Available at: <https://viewpointmag.com/2014/12/15/workerism-beyond-fordism-on-the-lineage-of-italian-workerism/> Accessed on: 30 April 2017.

CASTELLANO, Lucio (ed.). Aut. Op. La Storia e i documenti: da Potere operaio all'Atutonomia organizzata. Roma: Savelli, 1980.

Centro Ricerche sull'Autonomia Proletaria. Lotta alla innocenti. Primo Maggio, n. 7, 1976.

CHERKI, Eddi \& WIEVIORKA, Michel. Autoreduction movements in Turin. 1974. Semiotext(e), n. 3, 1980.

CLEAVER, Harry. Reading capital politically. Austin: University of Texas Press, 1979.

CONTINI, Giovanni. The rise and fall of shop floor bargaining at FIAT, 1945-1980. In: TOLLIDAY, Steven \& ZEITLIN, Jonathan (eds.). The automobile industry and its workers. Cambridge: Polity Press, 1986.

CUNNIGHAME, Patrick. Autonomia: a movement of refusal: social movements and social conflict in Italy in the 1970s. PhD thesis, Middlesex University, 2002.

Due vertenze esemplari. Rosso, anno 2, n. 8, 10 February 1974.

Editoriale. Rosso, anno 2, n. 1, Ocotber 1975.

Editoriale. Senza tregua. Giornale degli operai comunisti, 14 November 1975.

FASULO, Fabrizio. Raniero Panzieri and workers' inquiry: the perspective of living labour, the function of science and the relationship between class and capital, Ephemera, vol. 14, n. 3, 2014.

GLABERMAN, Martin (ed.). Marxism for our times: CLR James on Revolutionary Organization. Jackson, Miss.: Mississippi University Press, 1999.

Il festival del proletariato giovanile di Parco Lambro. // Manifesto. 3 September 2016.

Il quartiere ghetto delle Vallette. Rosso, anno 1, n. 1, 19 March 1973.

Intervento del compagno Mario di Novara. Lotta Continua, 28 August 1976.

LICHTENSTEIN, Nelson. State of the Union: a century of American labor. Princeton: Princeton University Press, 2002. 
LONGO, Biagio. Meno salario, più reddito: la cassa integrazione. Primo Maggio, n. 5, 1975.

MARAZZI, Christian. Moneta e capitale finanziario. In: ROGGERO, Gigi \& ZANIN, Adelino (eds.). Genealogie del futuro. Sette lezioni per sovvertire il presente. Verona: Ombre Corte, 2013.

NEGRI, Antonio. John M. Keynes e la teoria capitalistica dello stato nel '29. In: NEGRI, Antonio, et al. (eds). Operai e stato: lotte operaie e riforma dello stato capitalistico tra rivoluzione d'Ottobre e New Deal. Milano: Feltrinelli, 1972.

—. Proletari e Stato: per una discussione su autonomia operaia e compromesso storico. Milano: Feltrinelli, 1976.

—. Books for burning. Between civil war and democracy in 1970s Italy. London: Verso, 2005.

PALAZZI, David P. The 'social factory' in postwar Italian radical thought from Operaismo to Autonomia. Unpublished PhD dissertation. The City University of New York, 2014.

PANZIERI, Raniero. Spontaneità e organizzazione: gli anni del 'Quaderni rossi', 1959-1964. Pisa: BFS, 1994.

PIZZOLATO, Nicola. Transnational radicals: labour dissent and political activism in Detroit and Turin (19501970). International Review of Social History, vol. 56, n. 1, 2011.

RAMIREZ, Bruno. The working class struggle against the crisis: self-reduction of prices in Italy. Zerowork, n. 1, 1975.

REGALIA, Ida \& REGINI, Mario. Italy: the dual character of industrial relations. In: FERNER, A. \& HYMAN R. (eds.). Changing industrial relations in Europe. Oxford: Blackwell, 1998.

TARì, Marcello. // ghiaccio era sottile. Per una storia dell'Autonomia. Roma: DeriveApprodi, 2012.

Tronti, Mario. La fabbrica e la società. Quaderni rossi, n. 2, 1962.

—. Operai e capital. Torino: Einaudi, 1966.

TROTTA, Giuseppw \& MILANA, Fabio (eds.). L'operaismo degli anni sessanta. Da 'Quaderni rossi' a 'classe operaia'. Roma: DeriveApprodi, 2008.

Un fatto politico. Un fatto storico. Rosso, anno 1, n. 3, 16 April 1973.

VILLANI, Luciano. Neanche le otto lire. Lotte territoriali a Roma (1972-1975). Zapruder, n. 32, 2013.

WRIGHT, Steve. Negri's class analysis: Italian autonomist theory in the seventies. Reconstruction, n. 8, 1996.

_. Storming heaven: class composition and struggle in Italian autonomist marxism. London: Pluto Press, 2002. 